\title{
Quercetin Affects Hsp70/IRE1 $\alpha$ Mediated Protection from Death Induced by Endoplasmic Reticulum Stress
}

\author{
Antonello Storniolo, ${ }^{1}$ Marisa Raciti, ${ }^{1}$ Alessandra Cucina, ${ }^{2}$ \\ Mariano Bizzarri, ${ }^{1}$ and Livia Di Renzo ${ }^{1}$ \\ ${ }^{1}$ Department of Experimental Medicine, Sapienza University, Viale Regina Elena 324, 00161 Rome, Italy \\ ${ }^{2}$ Department of Surgery P. Valdoni, Sapienza University, Via A. Scarpa 14, 00161 Rome, Italy \\ Correspondence should be addressed to Livia Di Renzo; livia.direnzo@uniromal.it
}

Received 26 November 2014; Revised 9 March 2015; Accepted 16 March 2015

Academic Editor: Francisco Javier Romero

Copyright (C) 2015 Antonello Storniolo et al. This is an open access article distributed under the Creative Commons Attribution License, which permits unrestricted use, distribution, and reproduction in any medium, provided the original work is properly cited.

Relative to their normal counterparts, tumor cells generally exhibit a greater "stress phenotype" and express heat shock proteins (Hsp) that represent candidate targets for anticancer therapy. Here we investigated the role of Hsp70 in survival induced by endoplasmic reticulum (ER) stressors in human leukemia U937 cells. Quercetin, a major dietary flavonoid, or specific silencing affected the expression level of Hsp70 and did not allow the upregulation of inositol-requiring kinase $1 \alpha$ (IRE1 $\alpha$ ), the prototype ER stress sensor regulating the unfolded protein response (UPR), that protects the cells against the stress of misfolded proteins in the ER. The reduction of Hsp70 prevented the upregulation of immunoglobulin heavy-chain binding protein (BiP), but not of CCAAT/enhancer-binding protein-homologous protein (CHOP), and induced apoptosis. Also specific silencing of IREl $\alpha$ or inhibition of its endoribonuclease activity by $4 \mu 8 \mathrm{c}$ hampered the upregulation of BiP, but not of CHOP, and induced apoptosis. These results suggest that drugs affecting the Hsp70-IRE1 $\alpha$ axis, like quercetin, or affecting directly IREl $\alpha$ may represent an effective adjuvant antileukemia therapy.

\section{Introduction}

Disturbances in ER calcium homeostasis or protein processing cause the accumulation of misfolded or unfolded proteins in the ER, a cellular condition referred to as "ER stress." Adaptation to ER stress is mediated by the induction of the unfolded protein response (UPR), a regulated and complex signal transduction pathway transmitting information to the cytosol and nucleus to increase protein folding capacity of the ER [1-3]. However, cells undergo apoptosis when adaptation mechanisms are unable to alleviate the ER stress $[4,5]$. Thus, the UPR serves to mitigate the stress or, alternatively, to eliminate stressed cells in order to protect the organism.

The hallmark of the UPR is the upregulation of ER chaperones and folding enzymes, which are required to bind the unfolded proteins and prevent their aggregation [6]. Also a transient attenuation of protein synthesis participates to the UPR by limiting the load of proteins under conditions not well suited to their proper folding [7].
Three resident ER transmembrane sensors detect unfolded proteins in the ER to initiate three distinct UPR branches: inositol-requiring kinase- $1 \alpha$ (IRE1 $\alpha$ ), activating transcription factor-6 (ATF6), and protein kinase RNA- (PKR-) like ER kinase (PERK) [3, 6-8]. All these sensors have luminal domains that bind $\mathrm{BiP}$ under nonstress conditions. Once the ER stress leads to accumulation of unfolded proteins, $\mathrm{BiP}$ is released from the UPR sensors and binds to the unfolded proteins. These events trigger the activation of the ER sensors [9, 10]. IRE1 $\alpha$ is evolutionarily conserved from yeast to humans; it is a Ser/Thr protein kinase and endoribonuclease that, upon activation, initiates the splicing of the mRNA encoding Xbox binding protein 1 (XBP-1), converting it into a highly active transcription factor, termed XBP-1s. This is a key regulator of ER folding capacity that upregulates important genes related to control of protein quality, ER translocation, glycosylation, and ER/Golgi biogenesis $[11,12]$. XBP-1s regulates several UPR target genes including ER chaperones like $\mathrm{BiP}$, transcription factors like $\mathrm{CHOP}$, and other proteins [13]. 
$\mathrm{BiP}$ plays an antiapoptotic and cytoprotective role in early embryogenesis, oncogenesis, neurodegenerative diseases, and atherosclerosis [13, 14], while CHOP has been linked to apoptosis $[15,16]$. CHOP downregulates antiapoptotic proteins like $\mathrm{Bcl} 2$ and increases free oxygen species, causing mitochondrial membrane damage and cytochrome $\mathrm{C}$ release.

Heat shock proteins (Hsp), classified according to their approximate molecular size, comprise several members exhibiting different expression patterns or expressed in different cell compartments. The Hsp70 family has more than 8 members. It includes the major cytoplasmic forms called heat shock cognate (Hsc) 70, Hsp73, HspA8, Hsp70, the mitochondrial protein GRP75, and the endoplasmic reticulumresident GRP78. Hsc70 is constitutively and ubiquitously expressed. Hsp70, also named Hsp72, is generally expressed at very low or undetectable levels in unstressed normal cells while it is highly expressed in many malignant tumors, consistent with the idea that it represents a prosurvival factor, playing an essential role as chaperone in protein folding [1719]. Overexpressed Hsp72 can bind to IRE1 $\alpha$ and enhance its RNase activity, promoting adaptation to ER stress and cell survival [20]. A role of Hsp70 in tumorigenesis has been suggested, based on the fact that its overexpression in transgenic mice results in T-cell lymphoma [21]. The high expression of Hsp70 in tumor cells increases the resistance to apoptosis and has been associated with poor prognosis of cancer patients [22-25]. An altered expression or function of Hsp70 has been implicated in other human diseases, associated with defects in protein conformation or folding, as disorders caused by mutant proteins or some neurodegenerative diseases, such as Alzheimer's disease and Parkinson's disease [26, 27]. Furthermore, it is known that Hsp70 downregulation results in apoptosis in cancer cells but not in untransformed cells, which makes this protein an attractive target for molecular cancer therapeutics and chemoprevention.

In the present studies we set out to investigate the role of Hsp70, constitutively expressed in human monoblastic leukemia U937 cells, in the regulation of the UPR induced by the ER stressors tunicamycin (TN) and thapsigargin (TG). TN inhibits $\mathrm{N}$-linked glycosylation resulting in accumulation of misfolded proteins, whereas TG inhibits $\mathrm{Ca}^{++}$uptake by the ER, both resulting in ER stress induction. Hsp70 was silenced or its expression was reduced by quercetin (Q) [28], a major dietary flavonoid, that is going to be evaluated in a cancer clinical trial, based on its antiproliferative and antityrosine kinase activities [29].

The present studies demonstrate a functional link between Hsp70 and IRE1 $\alpha$ : targeting Hsp70 with Q or specific silencing, while not modifying CHOP upregulation, did not allow the upregulation of IRE1 $\alpha$ and BiP following ER stress and promoted cell death. These results indicate that quercetin, in combination with drugs causing endoplasmic reticulum stress, may represent an effective adjuvant antileukemia therapy.

\section{Materials and Methods}

2.1. Materials. Antibody anti- $\beta$-actin, BSA, FCS, HBSS, 1glutamine, penicillin-streptomycin, PBS, propidium iodide
(PI), Q, RNAse, RPMI-1640, and tunicamycin were from Sigma-Aldrich (St. Louis, MO, USA). Antibodies anti-BiP, -caspase 3, -CHOP, -Hsp70, -Hsp90, -IRE1 $\alpha$, and -PARP were from Cell Signaling Technology (Beverly, MA, USA). Horseradish peroxidase- (HRP-) conjugated anti-rabbit- and anti-mouse-immunoglobulin antibodies, enhanced chemiluminescence (ECL) reagents, and Hyperfilm-ECL film were from Amersham (Arlington Heights, IL, USA). Lipofectamine RNAiMAX and OPTI-MEM medium, small interfering- (siRNA-) IRE1, and relative scrambled siRNA (Ambion) were from Life Technologies (Invitrogen, San Giuliano Milanese, Italy). 2-Phenylethynesulfonamide (PES) and $4 \mu 8 \mathrm{c}$ were from Merck (INALCO, Milan, Italy). RCDC protein assay, SDS-sample buffer, protein standard, SDS-PAGE reagents, and polyvinylidene difluoride (PVDF) membranes were from Bio-Rad Laboratories (Segrate, Italy). Antibody anti-tubulin, siRNA-Hsp70, and scrambled siRNA were purchased from Santa Cruz Biotechnology (Tebu-Bio, Magenta, Italy). Thapsigargin and z-VAD.fmk were from Calbiochem (San Diego, CA, USA). Other reagents were of the highest purity and purchased from Bio-Rad, Invitrogen, or Sigma.

2.2. Cell Viability and Growth. The human monoblastic leukemia cell line U937, derived from a patient with diffuse histiocytic lymphoma, was used. Cells were grown in complete medium (RPMI-1640 medium supplemented with $5 \%$ heat-inactivated FCS, $2 \mathrm{mM}$ glutamine, 100 units $/ \mathrm{mL}$ penicillin, and $100 \mu \mathrm{g} / \mathrm{mL}$ streptomycin) at $37^{\circ} \mathrm{C}$, in fully humidified 95\% room air $/ 5 \% \mathrm{CO}_{2}$. Cells were resuspended three times a week in fresh complete medium to $3 \times 10^{5} / \mathrm{mL}$. Cell growth was evaluated by hemocytometry counts of cells excluding trypan blue ( $0.04 \%$ Trypan blue in PBS, w/v), and viability was assessed by calculating alive (trypan blue excluding) cells as percentage of all cells counted (trypan blue excluding and not excluding). Cells used in every experiment were $\geq 94 \%$ viable and taken from cultures in exponential growth. They were washed once and resuspended in complete medium, $1 \times 10^{6} / \mathrm{mL}$, and transferred to multiwell plates. They were then treated with inhibitors or vehicles, incubated for $30 \mathrm{~min}$, and subsequently exposed to test agents or, again, to vehicles. At the end of each experiment, the cells were gently mixed and aliquots were taken for cell counting, PI staining, and cell cycle analysis. The vehicles, even when used in combination, were $\leq 0.3 \%(\mathrm{v} / \mathrm{v})$ and did not modify any investigated parameter in comparison with control cultures.

\subsection{Flow Cytometry Analysis of Cell Death. Nuclear DNA} fragmentation was quantified by flow cytometry of hypodiploic (subG1) DNA after cell fixation and PI staining [30, 31]. Briefly, cells were washed with PBS, pelleted and fixed in ice cold ethanol/water $(70 / 30, \mathrm{v} / \mathrm{v})$ for $1 \mathrm{~h}$, pelleted again and washed twice with PBS, and finally resuspended in PBS containing RNAse $(20 \mu \mathrm{g} / \mathrm{mL})$ and PI $(100 \mu \mathrm{g} / \mathrm{mL})$. Events in the different cell cycle phases were gated manually using an EPICS XL cytofluorimeter (Beckman Coulter, Hialeah, Fl, USA). At least 10.000 events/sample were acquired. Collected data were analyzed using the Multicycle software for DNA 
content and cell cycle analysis (Phoenix Flow System, San Diego, CA, USA). The subG1 events representative of the apoptotic cells, and the events in the other cell cycle phases, are given as percentage of the total cell population.

Membrane permeability, indicative of cell death, was investigated by resuspending the cells in HBSS containing PI $(200 \mu \mathrm{g} / \mathrm{mL})$ at room temperature and analyzed by flow cytometry (EPICS-XL), measuring the fluorescence emission at $>575 \mathrm{~nm}$ (FL3).

2.4. Western Blot Analysis. Whole cell lysates were prepared as previously described [32]. Briefly, the cells were kept for $30 \mathrm{~min}$ on ice in lysis buffer $\left(\mathrm{NaCl} 150 \mathrm{mM}, \mathrm{CaCl}_{2} 1 \mathrm{mM}\right.$, $\mathrm{MgCl}_{2} 1 \mathrm{mM}, \mathrm{NaN}_{3}$ 0.1\%, NaF $10 \mathrm{mM}$, Triton X-100 1\% (v/v), orthovanadate $1 \mathrm{mM}$, aprotinin $2 \mu \mathrm{g} / \mathrm{mL}$, leupeptin $2 \mu \mathrm{g} / \mathrm{mL}$, iodoacetamide $10 \mathrm{mM}$, PMSF $2 \mathrm{mM}$, and pepstatin $20 \mu \mathrm{M})$. The appropriate volumes of $4 \mathrm{x}$ SDS-sample buffer $(\mathrm{v} / \mathrm{v})$ were then added. Cell lysates were briefly sonicated, warmed at $95^{\circ} \mathrm{C}$ for $5 \mathrm{~min}$, and cleared by $14000 \times \mathrm{g}$ centrifugation in a microfuge for $15 \mathrm{~min}$ at $4^{\circ} \mathrm{C}$. Supernatants were collected and proteins were quantified by RC DC protein assay. Equal amounts of proteins were separated from the different samples by SDS-PAGE, and blotted onto PVDF membranes. Transfer efficiency was checked with Ponceau staining. The blots were blocked in tris-buffered saline (TBS) containing BSA 5\% (w/v), probed with specific primary antibodies (anti-BiP, -CHOP, -Hsp70, -IRE1 $\alpha$, or -PARP), washed with PBS-Tween 20, and then incubated with the appropriate peroxidase-conjugated secondary antibody. Finally, in order to control protein loading, each membrane was probed to detect $\beta$-actin, tubulin, Hsp90, or caspase 3 and the appropriate peroxidase-conjugated secondary antibody. For each antibody were used the dilutions and incubation times suggested by the manufacturer. Immunodetection was performed using the ECL reagents and Hyperfilm-ECL film. Densitometry quantitation of the bands was performed using ImageJ software (National Institutes of Health, Bethesda, MD, USA) on a Mac OS X (Apple Computer International, Cupertino, CA, USA).

2.5. siRNA. RNA knockdown was performed with pools of siRNA duplexes. Briefly, cells were washed and resuspended in OPTI-MEM medium, transfected with siRNA specific for human Hsp70 and scrambled siRNA (Santa-Cruz) or with siRNA specific for IRE1 $\alpha$ and relative scrambled siRNA (Ambion), using Lipofectamine RNAiMAX according to the manufacturer's guidelines and as we previously described [33]. After $12 \mathrm{~h}$ of incubation, RPMI 1640 containing 20\% fetal calf serum was added without removing the transfection medium. The cells were cultured for further $60 \mathrm{~h}$. After centrifugation, the medium was replaced with fresh RPMI1640 , containing $10 \%$ fetal calf serum, and the cells cultured again in the presence or not of TN.

2.6. Statistical Analysis. Results are expressed as the mean \pm standard deviation (SD) of repeated experiments, as indicated in the figure legends. Statistical differences between the data sets were evaluated using unpaired, two-tailed Student's $t$ test. Values of $P<0.05$ were considered statistically significant.

\section{Results}

3.1. Survival of U937 Cells under Moderate ER Stress Conditions. TN and TG are ER stressors that induce U937 cell death in a dose-dependent manner and that activate a prosurvival pathway at low concentrations [33]. In particular, TN $(1 \mu \mathrm{M})$ caused a moderate increase of PI incorporating (PI+) cells $(18 \pm 7 \%)$ in comparison with untreated cultures $(6 \pm 1 \%)$ (Figure 1(a)), in addition to the appearance of $19 \pm 6 \%$ of subG1 events (Figure 1(b)). Similarly, TG (200 nM) caused a fall in cell viability (PI+ cells $23 \pm 5 \%$ ) (Figure $1(\mathrm{a})$ ) and induced the appearance of sub-G1 events $(24 \pm 7 \%$ ) (Figure $1(\mathrm{~b}))$. Sub-G1 events were studied by cytofluorimetry of cell cycle phases of cells fixed and stained with PI. The hypodiploid DNA events were easily discernible from the narrow peak of cells with diploid DNA content; they are considered to be indicative of apoptotic nuclei [30, 33]. Furthermore, analysis of events in the different cell cycle phases showed that TN $(1 \mu \mathrm{M})$ and TG $(200 \mathrm{nM})$ caused a decrease in $\mathrm{S}$ and G2M phases, while the percentage of G1 events were apparently unchanged (Figure 1(c)). Cell counts indicated that neither TN nor TG allowed cell growth (not shown). These results show that these ER stressors, at the indicated low concentrations, cause activation of a prosurvival pathway in U937 cells, arrested in G1 cell cycle phase. To investigate this prosurvival pathway, all the experiments were performed with TN $1 \mu \mathrm{M}$ and TG $200 \mathrm{nM}$, and viability parameters were investigated after $24 \mathrm{~h}$.

\subsection{Quercetin Downregulates the Expression of Hsp70 in U937} Cells. Hsp70 is present at constitutively high levels in various human tumors, in contrast to its low expression in unstressed normal cells. It is an important chaperone that plays a key role in conformational maturation and stabilization of proteins involved in cell growth and survival. Also U937 tumor cells express constitutively rather high levels of Hsp70, not apparently modified by the ER stress induced by TN or TG (Figure 2(a)). Q is known to inhibit the synthesis of Hsp70 in some human cancer cell lines [28]. This flavonoid, at high doses, is cytotoxic and can block proliferation of U937 cells (unpublished results). Thus, we used the concentration $10 \mu \mathrm{M}$ to avoid its cytotoxic effects. We found that quercetin (30 min, cell pretreatment) reduced the expression of Hsp70 in U937 cells under basal conditions as well as upon TN or TG treatments (Figure 2(a)).

3.3. Hsp70 Protects ER Stressed Cells from Death. Q caused per se a moderate increase of U937 cell death, as determined by evaluation of PI+ cells $(14 \pm 4 \%)$ and sub-G1 events $(13 \pm$ $3 \%$ ) (Figures 2(b) and 2(c)). However, when combined with TN or TG, it caused a conspicuous increase of PI+ cells and sub-G1 events (Figures 2(b) and 2(c)). Thus, Q turns the survival induced by the ER stressors into cell death. PES is a pharmacological inhibitor of Hsp70 $[34,35]$. It $(10 \mu \mathrm{M}$, 


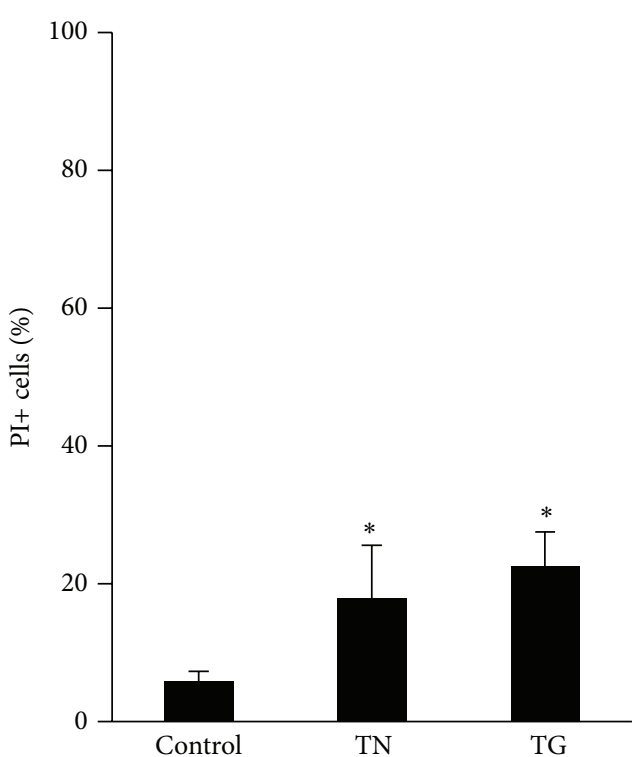

(a)

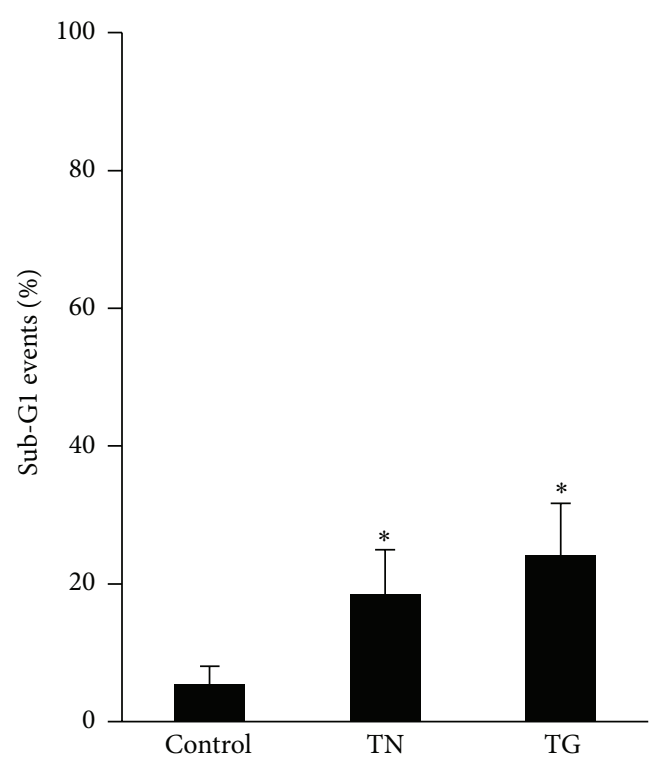

(b)

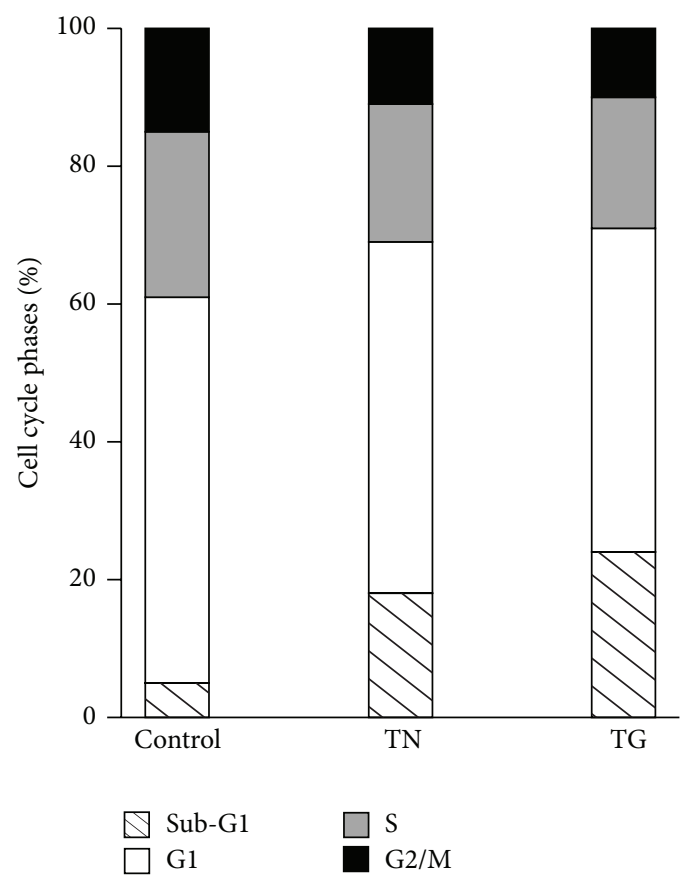

(c)

FIGURE 1: Low doses of the ER stressors, TN or TG, are not cytotoxic to U937 cells. U937 cells either exposed or not to TN $1 \mu \mathrm{M}$ or TG $200 \mathrm{nM}$ for $24 \mathrm{~h}$. (a) A cell portion was unfixed, stained with PI and immediately $\geq 10000$ events were analyzed in a cytofluorimeter in order to evaluate the dead cells incorporating PI as percentage of total events. (b and c) A cell portion was fixed and thereafter stained with PI in order to evaluate by cytofluorimetry, among $\geq 10000$ events, those in sub-G1 (b) and in sub-G1, G1, S, and G2M (c) of the cell cycle. The reported values represent the means and error bars, the S.D. of dead cells (PI+), or sub-G1 events of 12 independent experiments. Assessment of cell death showed statistically significant differences between the data obtained in the cultures treated with TN or TG in comparison with the untreated cultures $\left({ }^{*} \mathrm{P}<0.0001\right)$.

30 min cell pretreatment) was slightly cytotoxic for U937 cells (PI+ cells $14 \pm 3 \%$; sub-G1 events $10.7 \pm 3 \%$ ) and more cytotoxic when associated with TN or TG (Figures 2(b) and 2(c)). In order to rule out off-target effects of the pharmacological inhibitors, Hsp70 expression was silenced by specific siRNA. After transfection time $(72 \mathrm{~h})$, TN was added for the subsequent $24 \mathrm{~h}$. In comparison with scrsiRNA, Hsp70 specific silencing brought about an effective reduction of Hsp70 (Figure 2(d)) and caused a strong increase of cell death in ER stressed cells (Figure 2(e)). 


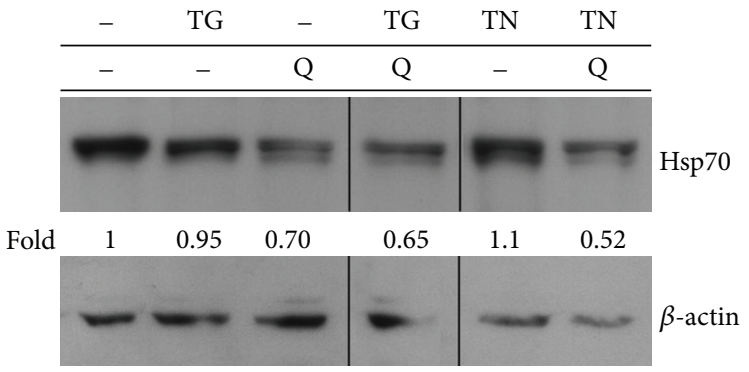

(a)

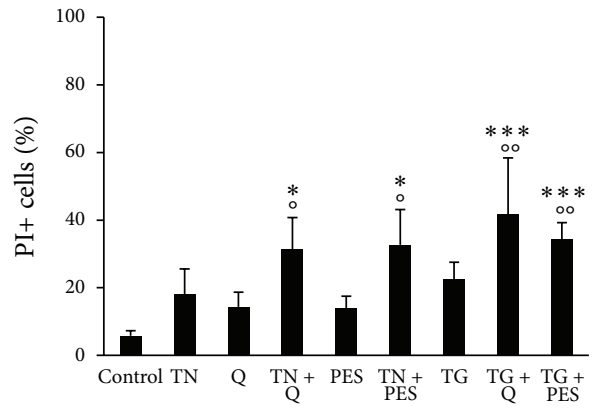

(b)

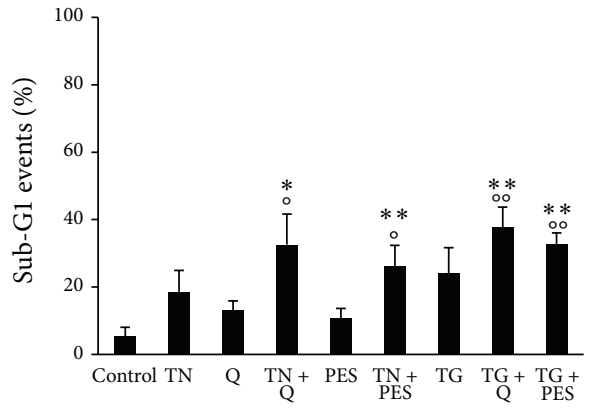

(c)

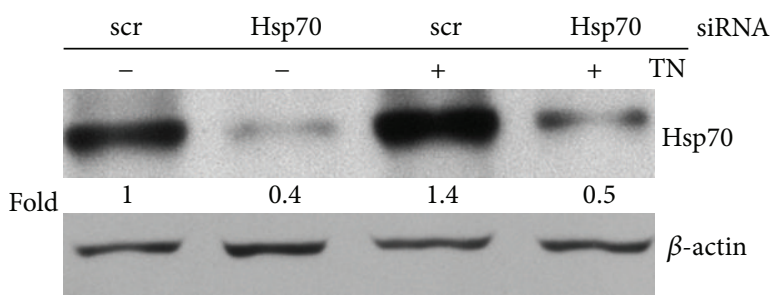

(d)

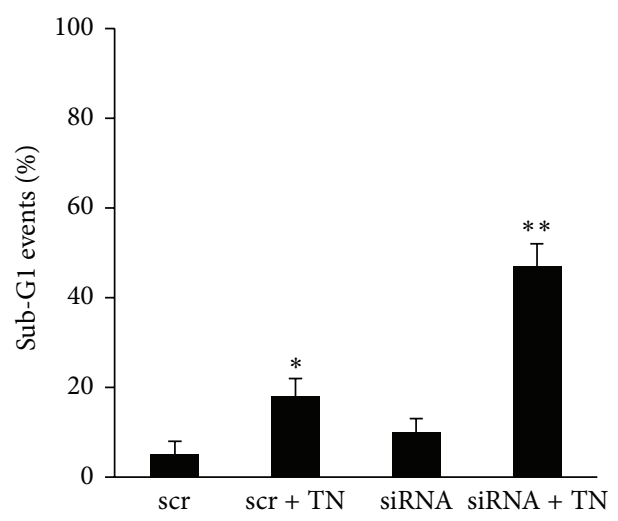

(e)

FIGURE 2: Hsp70 promotes survival of ER stressed cells. (a) Hsp70 was detected by western blot in the lysates of U937 cells either exposed or not to Q $(10 \mu \mathrm{M}, 30 \mathrm{~min})$ and thereafter to none or TN $1 \mu \mathrm{M}$ or TG $200 \mathrm{nM}$ for $24 \mathrm{~h}$. Blotted proteins were probed with anti-Hsp70 followed by peroxidase-conjugated secondary antibody. Western blot of $\beta$-actin is shown at the bottom as a loading control. Representative blots are shown. Densitometric quantification of the bands is shown at the bottom of the relevant lines as the ratio of Hsp70 in each line to the Hsp70 value observed in the lysate of untreated U937 cells. (b and c) Detection of cell death by evaluation of PI+ cells (b) or of sub-G1 events (c). U937 cells were pretreated for $30 \mathrm{~min}$ with none or Q $(10 \mu \mathrm{M})$ or PES $(10 \mu \mathrm{M})$ and then with none or TN $(1 \mu \mathrm{M})$ or TG $(200 \mathrm{nM})$. A portion of cells were unfixed and stained with PI (b) or fixed and stained with PI to evaluate sub-G1 events in the cell cycle (c) under cytofluorimetry. Both types of investigation were performed on $\geq 10000$ events. The values reported are means \pm S.D. $(n=6)$. Assessment of cell death showed statistically significant differences between the data obtained in the cultures treated with TN or TG together with Q or with PES, in comparison with the cultures treated only with Q $\left({ }^{\circ} \mathrm{P}<0.0001\right)$ or only with PES $\left({ }^{\circ} \mathrm{P}<0.0001\right)$ or only with TN or TG $\left({ }^{*} P<0.0001 ;{ }^{* *} P<0.003 ;{ }^{* * *} P<0.03\right)$. (d) Western blot analysis of Hsp70 by specific antibody in the lysates of U937 cells transfected with equal amounts of Hsp70 siRNA or scr-siRNA for $72 \mathrm{~h}$ and exposed to none or to TN $1 \mu \mathrm{M}$ for further $24 \mathrm{~h}$. Western blot analysis of $\beta$-actin is shown at the bottom, as a loading control and also to confirm the specificity of the transfected siRNA. Representative blots are shown. Densitometric quantification of the bands is shown at the bottom of the relevant lines as the ratio of Hsp70 in each line to the Hsp70 value observed in the lysate of untreated U937 cells transfected with scrambled siRNA. (e) U937 cells transfected with Hsp70 siRNA or scr-siRNA for $72 \mathrm{~h}$ and exposed or not to TN $1 \mu \mathrm{M}$ for $24 \mathrm{~h}$ were fixed with ethanol, stained with PI, and analyzed under cytofluorimetry to detect subG1 events in the cell cycle. Here are shown the mean \pm S.D. of four independent experiments. Assessment of cell death showed statistically significant differences between the data obtained in the cultures treated with scr-siRNA and TN in comparison with the cultures treated only with scr-siRNA $\left({ }^{*} P<0.005\right)$ or with Hsp70 siRNA and TN in comparison with scr-siRNA or Hsp70 siRNA $\left({ }^{* *} P=0.001\right)$. 


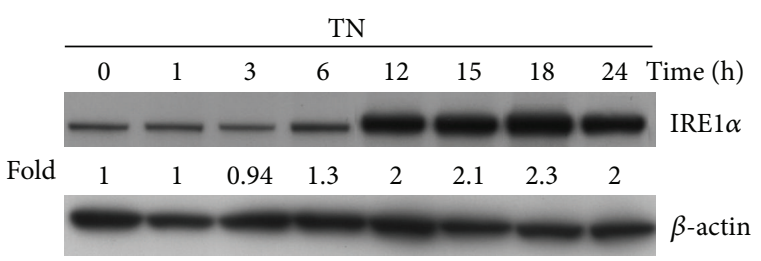

(a)

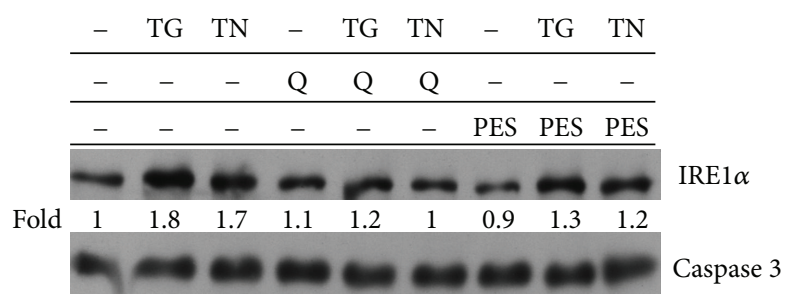

(b)

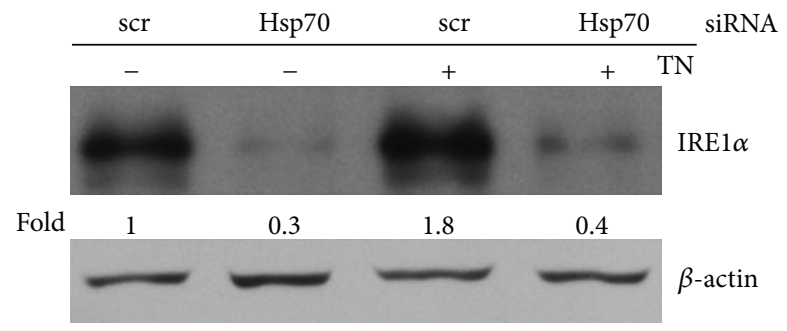

(c)

FIGURE 3: IRE1 $\alpha$ expression is linked to Hsp70. (a) Western blot was performed with anti-IRE1 $\alpha$ followed by peroxidase-conjugated secondary antibody to analyze this ER sensor in the lysates of untreated $(0 \mathrm{~h})$ or TN treated U937 cells for the hours indicated. Western blot of $\beta$-actin is shown at the bottom as a loading control. Representative blots are shown. Densitometric quantification of the bands is shown at the bottom of the relevant lines as the ratio of IRE1 $\alpha$ in each line to the IRE1 $\alpha$ value observed in the lysate of untreated U937 cells. (b) Western blot was performed with anti-IRE1 $\alpha$ followed by peroxidase-conjugated secondary antibody to analyze this ER sensor in the lysates of untreated cells or Q $(10 \mu \mathrm{M})$ or PES $(10 \mu \mathrm{M})$ pretreated cells, thereafter treated with none or TN or TG for $24 \mathrm{~h}$. Western blot of caspase 3 is shown at the bottom as a loading control. Representative blots are shown. Densitometric quantification of the bands is shown at the bottom of the relevant lines as the ratio of IRE1 $\alpha$ in each line to the IRE1 $\alpha$ value observed in the lysate of untreated U937 cells. (c) Western blot analysis of IRE1 $\alpha$ by specific antibody in the lysates of U937 cells transfected with equal amounts of Hsp70 siRNA or scr-siRNA (Santa Cruz) for $72 \mathrm{~h}$ and exposed to none or to TN $1 \mu \mathrm{M}$ for further $24 \mathrm{~h}$. Western blot analysis of $\beta$-actin is shown at the bottom, as a loading control and also to confirm the specificity of the transfected siRNA. Representative blots are shown. Densitometric quantification of the bands is shown at the bottom of the relevant lines as the ratio of IRE1 $\alpha$ in each line to the IRE1 $\alpha$ value observed in the lysate of untreated U937 cells transfected with scrambled siRNA.

These results show that Hsp70 promotes survival of ER stressed cells.

3.4. Hsp70 and IRE1 $\alpha$ Are Functionally Linked. Among the three major transmembrane sensors of ER stress (IRE1 $\alpha$, PERK, and ATF6), IRE1 $\alpha$ is the prototype ER stress sensor, evolutionarily conserved from yeast to human. The cytoprotective output of IRE1 $\alpha$ is present across all eukaryotes. We examined the expression level of this sensor in U937 cells treated with TN and found that it was upregulated after $6 \mathrm{~h}$, even more after 12,15 , and $18 \mathrm{~h}$, and it remained high after $24 \mathrm{~h}$ (Figure 3(a)). Similar results were obtained using TG, as ER stressor (not shown).

In order to investigate the link between Hsp70 and IRE1 $\alpha$, U937 cells were pretreated with Q or PES, as the former drug affects Hsp70 expression, while the latter inhibits it. Both pretreatments prevented the upregulation of IRE1 $\alpha$ following ER stress (Figure 3(b)). To rule out any unspecific effect of the used inhibitors, IRE1 $\alpha$ was analyzed by western blot in cells silenced for Hsp70. In comparison with scr-siRNA, Hsp70 silencing effectively decreased the expression of constitutive IRE $1 \alpha$ and prevented the increased expression of this ER sensor caused by TN treatment (Figure 3(c)).

These experiments indicate a functional link between Hsp70 and IRE1 $\alpha$.

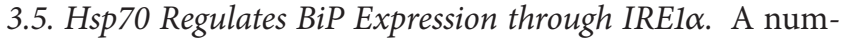
ber of studies have shown that cell survival or death decisions during the UPR are, respectively, mediated via the antiapoptotic $\mathrm{BiP}$ or the proapoptotic $\mathrm{CHOP}$. We therefore examined the expression of these proteins by western blot in ER stressed U937 cells. TN, as previously reported, resulted in upregulation of $\mathrm{BiP}$ and $\mathrm{CHOP}$, which became evident after $6 \mathrm{~h}$ and increased after 12 and $24 \mathrm{~h}$ of treatment [33]; quercetin or specific silencing of Hsp70 did not influence the expression of $\mathrm{CHOP}$, while they prevented substantially BiP upregulation (Figures 4(a) and 4(b)).

IRE1 $\alpha$ is a Ser/Thr protein kinase and endoribonuclease that, upon activation, initiates the unconventional splicing of the X-box binding protein (XBP-1) mRNA. The product of this splicing is XBP-1s, a highly active transcription factor and one of the key regulators of ER folding capacity. $4 \mu 8 \mathrm{c}$ is an inhibitor of IRE1 $\alpha$ endoribonuclease activity [36]. IRE1 $\alpha$ inhibition with $4 \mu 8 \mathrm{c}(10 \mu \mathrm{M}$, cell pretreatment $30 \mathrm{~min})$ or its specific silencing prevented $\mathrm{BiP}$, but not $\mathrm{CHOP}$ induction after $24 \mathrm{~h}$ of TN treatment (Figures 4(a) and 4(b)). When TG was used, similar results were observed (not shown). The inhibition of IRE1 $\alpha$ by $4 \mu 8 \mathrm{c}$ caused a slight increase of sub-G1 events, more evident after TN treatment (Figure 5(c)).

These results indicate that in U937 cells undergoing a moderate ER stress Hsp70 promotes BiP upregulation 


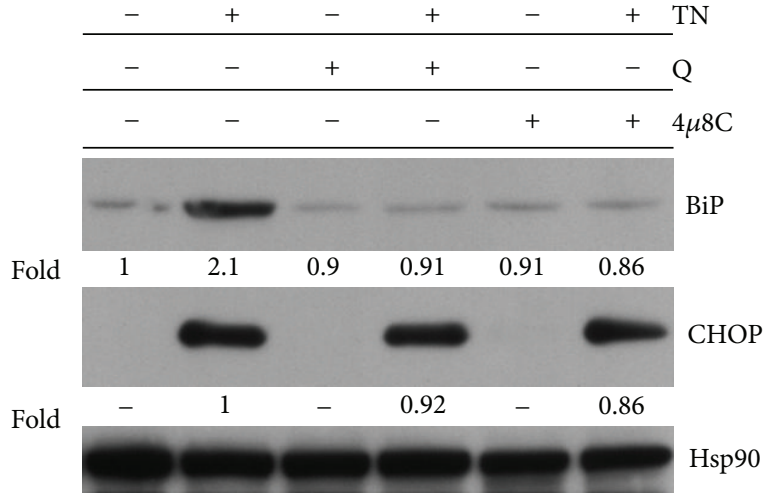

(a)

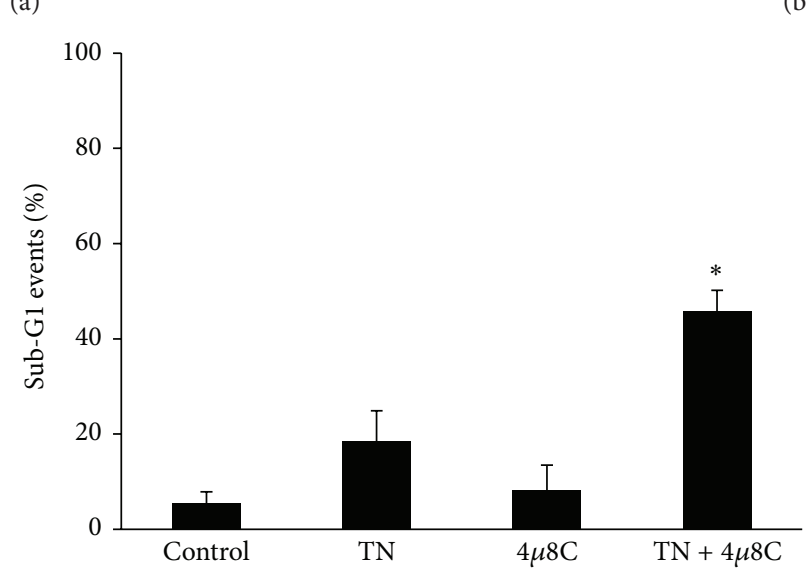

(c)

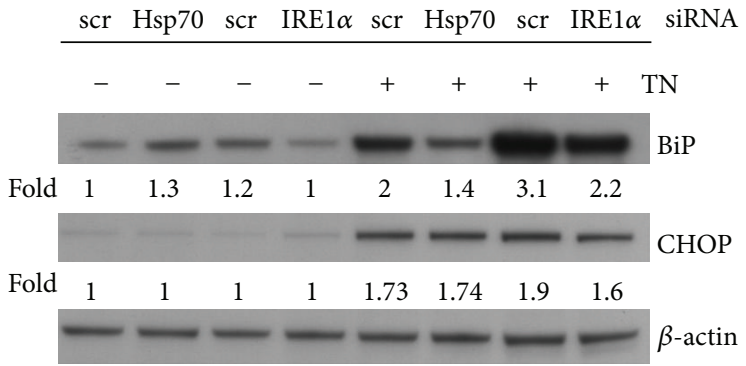

(b)

FIGURE 4: Impairment of Hsp70 prevents upregulation of BiP but not of CHOP. (a) Western blot was performed with anti-BiP or anti-CHOP followed by peroxidase-conjugated specific secondary antibody to analyze these proteins in the lysates of untreated cells or Q (10 $\mu \mathrm{M})$ or $4 \mu 8 \mathrm{c}$ $(10 \mu \mathrm{M})$ pretreated cells and thereafter treated with none or TN for $24 \mathrm{~h}$. Western blot of Hsp90 is shown at the bottom as a loading control. Representative blots are shown. Densitometric quantification of the bands is shown at the bottom of the relevant lines as the ratio of BiP or $\mathrm{CHOP}$ in each line, respectively, to the $\mathrm{BiP}$ or $\mathrm{CHOP}$ values observed in the lysate of untreated U937 cells or to the CHOP value observed in $\mathrm{TN}$ treated cells. Western blot analysis of Hsp90 is shown at the bottom, as a loading control. (b) Western blot analysis of BiP or CHOP by specific antibody in the lysates of U937 cells transfected with equal amounts of Hsp70 siRNA or scr-siRNA (Santa Cruz) or equal amounts of IRE1 $\alpha$ siRNA or scr-siRNA (Ambion) for $72 \mathrm{~h}$ and exposed to none or to TN $1 \mu \mathrm{M}$ for further $24 \mathrm{~h}$. Western blot analysis of $\beta$-actin is shown at the bottom, as a loading control and also to confirm the specificity of the transfected siRNA. Representative blots are shown. Densitometric quantification of the bands is shown at the bottom of the relevant lines as the ratio of BiP or CHOP in each line, respectively, to the BiP or CHOP values observed in the lysate of untreated U937 cells transfected with scrambled siRNA (Santa Cruz). (c) Detection of cell death by evaluation of sub-G1 events. U937 cells were pretreated for $30 \mathrm{~min}$ with none or $4 \mu 8 \mathrm{c}(10 \mu \mathrm{M})$ and thereafter for $24 \mathrm{~h}$ with none or TN $(1 \mu \mathrm{M})$. The cells were fixed and stained with PI to evaluate sub-G1 events in the cell cycle by cytofluorimetric analysis performed on $\geq 10000$ events. The values reported are means \pm S.D. $(n=5)$. Assessment of cell death showed statistically significant differences between the data obtained in the cultures treated with TN and $4 \mu 8 \mathrm{c}$ in comparison with the cultures treated only with $\mathrm{TN}\left({ }^{*} P<0.0001\right)$.

through IREl $\alpha$ activity and that this ER sensor plays a prosurvival role.

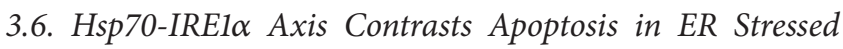
Cells. TN and TG induce apoptosis in U937 cells as above and previously reported [33]. Here we show that in these cells PARP-1 was cleaved, indicating caspase 3 activation (Figure 5(a)). Furthermore, conditions affecting Hsp70 expression, that is, the use of $\mathrm{Q}$ or specific silencing of Hsp70, increased PARP-1 cleavage, which appeared more conspicuous after cell treatment with TN (Figures 5(a) and $5(b))$.
Detection by flow cytometry of sub-G1 events is considered to be indicative of apoptosis. An increase of sub-G1 events was observed after Hsp70 impairment with Q or after IRE1 $\alpha$ inhibition with $4 \mu 8 \mathrm{c}$ that was prevented by the use of $\mathrm{z}$-VAD.fmk, a pan-caspase inhibitor $(70 \mu \mathrm{M}$, pretreatment for 60 min) (Figure 5(c)).

These results indicate that either the impairment of Hsp70 expression or the inhibition of IRE1 $\alpha$ endoribonuclease activity cause apoptosis of ER stressed U937 cells. Taken together, these findings suggest that Hsp70-IRE1 $\alpha$ axis is a kind of hub around which are regulated survival and apoptosis mechanisms. 


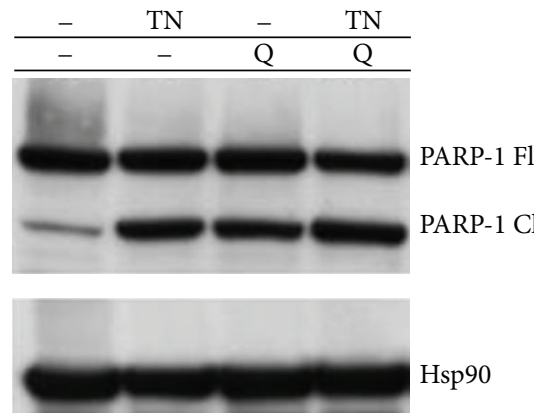

(a)

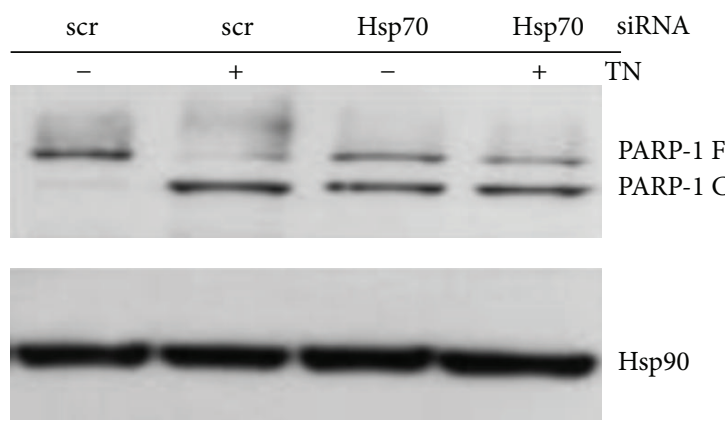

(b)

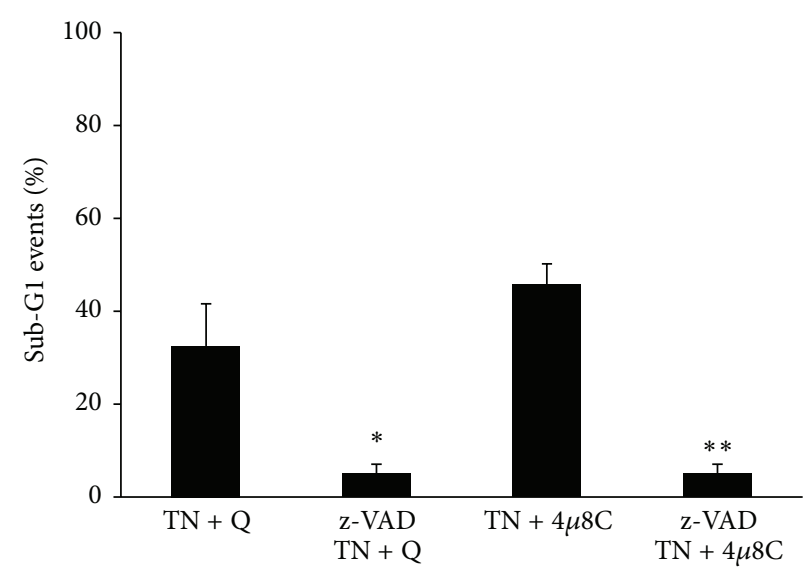

(c)

FIGURE 5: Hsp70-IRE1 $\alpha$ axis protects from apoptosis. (a) Q induces fragmentation of PARP-1. Western blot was performed with anti-PARP-1 followed by peroxidase-conjugated secondary antibody to analyze this protein (FL $=$ full length; $\mathrm{CL}=$ cleaved) in the lysates of untreated or $\mathrm{Q}(10 \mu \mathrm{M})$ pretreated cells and thereafter treated with none or TN for $24 \mathrm{~h}$. Western blot of Hsp90 is shown at the bottom as a loading control. Representative blots are shown. (b) Western blot analysis of PARP-1 (FL = full length; CL = cleaved) by specific antibody in the lysates of U937 cells transfected with equal amounts of Hsp70 siRNA or scr-siRNA (Santa Cruz) for $72 \mathrm{~h}$ and exposed to none or to TN $1 \mu \mathrm{M}$ for further $24 \mathrm{~h}$. Western blot analysis of Hsp90 is shown at the bottom, as a loading control and also to confirm the specificity of the transfected siRNA. Representative blots are shown. (c) Detection of cell death by evaluation of sub-G1 events. U937 cells were pretreated for 60 min with none or z-VAD.fmk $(70 \mu \mathrm{M})$, then for further 30 min with none or Q $(10 \mu \mathrm{M})$ or $4 \mu 8 \mathrm{c}(10 \mu \mathrm{M})$, and thereafter for $24 \mathrm{~h}$ with none or TN $(1 \mu \mathrm{M})$. The cells were fixed and stained with PI to evaluate sub-G1 events in the cell cycle by cytofluorimetric analysis performed on $\geq 10000$ events. The values reported are means \pm S.D. $(n=5)$. Assessment of cell death showed statistically significant differences between the data obtained in the cultures treated with TN and Q and z-VAD in comparison with the cultures treated only with TN and Q $\left({ }^{*} P<0.0001\right)$ or between the data obtained in the cultures treated with TN and $4 \mu 8 \mathrm{c}$ and $\mathrm{z}$-VAD in comparison with the cultures treated only with TN and $4 \mu 8 \mathrm{c}\left({ }^{* *} P<0.0001\right)$.

\section{Discussion}

ER stress-activated gene transcription is mediated by three different but interconnected pathways: PERK-ATF-4, ATF6, and IRE $1 \alpha-\mathrm{XBP}-1$ s. The transducers of these pathways (PERK, ATF6, and IRE1 $\alpha$ ) sense the presence of unfolded proteins in the ER lumen and convey this information to the nucleus. IRE1 $\alpha$ activation leads to XBP-1 alternative splicing and, among other proteins, to $\mathrm{BiP}$ upregulation involved in cell survival [9-13]. It is known that the knocking down of IREl $\alpha$ enhances cell death under conditions of chronic ER stress and that prolonging of IRE1 $\alpha$ signaling, independently of ER stress, can promote cell survival [37-39].

A functional crosstalk between Hsp70 and ER stress has been observed in a number of physiological and pathological conditions, such as a cellular model of Parkinson's disease induced by 6-hydroxy dopamine (6-OHDA) or following proteasome inhibition $[40,41]$. It has also been reported that the regulation of the UPR is associated with the formation of a stable complex between Hsp72 and the cytosolic domain of IRE1 $\alpha$ and that Hsp72, although having no effect on the halflife of this ER sensor, enhances its RNase activity, suggesting a direct interaction [20]. Overall, those results have shown that Hsp72 is a component of the UPRosome that, by binding IRE1 $\alpha$, enhances XBP-1 signaling and promotes adaptation to ER stress and cell survival.

In the present work we set out to explore the relationship between Hsp70 expressed by U937 leukemia cells and IRE1 $\alpha$, in order to test the hypothesis that constitutive Hsp70, enhancing the amplitude of IRE1 $\alpha$ signaling, promotes cell survival under conditions of ER stress. To this end, we used doses of ER stressors causing a moderate ER stress allowing the survival of U937 cells and we inhibited Hsp70 expression by $\mathrm{Q}$ or specific siRNA. 
The induction of the Hsp in higher organisms is regulated at the transcriptional and translational levels. The transcription of heat shock genes is regulated by the cis-acting heat shock element (HSE) in the promoter region and the transacting heat shock factor (HSF). Q action has been examined on the promoter region of the human $H s p 70$ gene, especially on the formation of the HSF-HSE complex after activation either in vivo by heat shock or in vitro by heat treatment, urea, or Nonidet P-40 [28]. It was detected that Q inhibits the binding of HSF to the HSE both in vivo and in vitro. Thus, Q interaction with HSF leads to the inhibition of this transcription factor and of Hsp70 [28]. Our studies have confirmed that this flavonoid affects Hsp70 expression also in human U937 cells under basal conditions and upon ER stress.

Q or specific silencing of Hsp70 prevented also the upregulation of IRE1 $\alpha$ induced by ER stress, suggesting a functional link between Hsp70 and IREl $\alpha$, allowing the increased expression of the latter protein under conditions of ER stress that could be due to an increased translation of IRE1 $\alpha$ or to a physical connection leading to an increased half-life of IRE1 $\alpha$. Although we did not explore the link of Hsp70 to the UPRosome, we were able to pinpoint that, under ER stress, the Hsp70-IREl $\alpha$ axis permits the upregulation of $\mathrm{BiP}$, while it is not affecting CHOP in U937 cells. In fact, the ER stressors induced both $\mathrm{BiP}$ and $\mathrm{CHOP}$, while IRE1 $\alpha$ downregulation prevented only the expression of BiP. However, the cells survived when both $\mathrm{BiP}$ and $\mathrm{CHOP}$ expression increased, while apoptosis was induced after inhibition of the Hsp70-IREl $\alpha$ axis and BiP downregulation. The same effect on cell survival was obtained also after specific silencing of IRE1 $\alpha$ or inhibition of its endoribonuclease activity with $4 \mu 8 \mathrm{c}$. Thus, Hsp70, by regulating IRE1 $\alpha$ expression, plays a role in a survival pathway featuring $\mathrm{BiP}$, since this protein is antiapoptotic and prevents ER stress-induced cell death $[13,14]$.

The accumulation of unfolded proteins following ER stress, in defect of IRE1 $\alpha$, is supposed to lead to the activation of the other two sensors [42]. In this context the concomitant decrease of BiP may represent a crucial step, as this protein is an inhibitory chaperone of the three ER sensors. Thus, the possible activation of PERK, via ATF4, may cause the increased expression of the proapoptotic CHOP. As this scenario generally occurs in severe ER stress $[42,43]$, we hypothesize that the impairment of the Hsp70-IRE1 $\alpha$ axis turns a mild ER stress into a severe ER stress, associated with increased expression of CHOP.

In conclusion, in this study we show that quercetin, a major dietary flavonoid, downregulates the expression of Hsp70 in monoblastic leukemia U937 cells. Quercetin or specific Hsp70 siRNA prevents the upregulation of IRE1 $\alpha$ and $\mathrm{BiP}$, during endoplasmic reticulum stress, induced by TN or TG. This condition of ER stress and dysregulation of IRE1 $\alpha$ and $\mathrm{BiP}$ promotes cell death.

These results indicate that, during ER stress, Hsp70 and IRE1 $\alpha$ represent candidate targets to kill leukemia cells and that quercetin may be employed at this purpose.

\author{
Abbreviations

$\begin{array}{ll}\text { ATF6: } & \text { Activating transcription factor } 6 \\ \text { BiP: } & \text { Immunoglobulin heavy-chain } \\ & \text { binding protein } \\ \text { BSA: } & \text { Bovine serum albumin } \\ \text { CHOP: } & \text { CCAAT/enhancer-binding } \\ & \text { protein-homologous protein } \\ \text { ECL: } & \text { Enhanced chemiluminescence } \\ \text { ER: } & \text { Endoplasmic reticulum } \\ \text { FCS: } & \text { Fetal calf serum } \\ \text { GRP78: } & \text { 78 kDa glucose-regulated protein } \\ \text { HRP: } & \text { Horseradish peroxidase } \\ \text { Hsp: } & \text { Heat shock protein } \\ \text { IRE1 } \alpha: & \text { Inositol-requiring kinase } 1 \alpha \\ \text { PBS: } & \text { Phosphate buffered saline } \\ \text { PERK: } & \text { Protein kinase RNA- (PKR-) like } \\ \text { PES: } & \text { ER kinase } \\ \text { PI: } & \text { 2-Phenylethynesulfonamide } \\ \text { PVDF: } & \text { Propidium iodide } \\ \text { Q: } & \text { Polyvinylidene difluoride } \\ \text { RC-DC protein assay: } & \text { Reducing agent and detergent } \\ \text { SDS-PAGE: } & \text { compatible protein assay } \\ \text { TG: } & \text { Sodium-dodecyl-sulphate- } \\ \text { UPR: } & \text { polyacrylamide gel } \\ \text { XBP-1: } & \text { electrophoresis } \\ \text { siRNA: } & \text { Small interfering RNA } \\ \text { TBS: } & \text { Tris-buffered saline } \\ & \text { Thapsigargin } \\ & \text { Unfolded protein response } \\ & \\ \text { TGox binding protein 1. }\end{array}$

\section{Conflict of Interests}

The authors declare that they have no conflict of interests relating to the present study.

\section{Authors' Contribution}

Antonello Storniolo performed most of the experiments, participated in the study design, and analyzed results. Marisa Raciti performed several experiments. Alessandra Cucina and Mariano Bizzarri participated in the study design and analyzed the results. Livia Di Renzo designed the experiments, analyzed the results, coordinated the study group, and wrote the paper.

\section{Acknowledgments}

This work was supported by grants to Livia Di Renzo from Sapienza Ateneo 2011 (8.1.1.1.34.1) and Sapienza Ateneo 2012 (8.1.1.1.38.1).

\section{References}

[1] R. J. Kaufman, "Stress signaling from the lumen of the endoplasmic reticulum: coordination of gene transcriptional and 
translational controls," Genes \& Development, vol. 13, pp. 12111233, 1999.

[2] H. P. Harding, M. Calfon, F. Urano, I. Novoa, and D. Ron, "Transcriptional and translational control in the mammalian unfolded protein response," Annual Review of Cell and Developmental Biology, vol. 18, pp. 575-599, 2002.

[3] D. Ron and P. Walter, "Signal integration in the endoplasmic reticulum unfolded protein response," Nature Reviews Molecular Cell Biology, vol. 8, no. 7, pp. 519-529, 2007.

[4] E. Szegezdi, S. E. Logue, A. M. Gorman, and A. Samali, "Mediators of endoplasmic reticulum stress-induced apoptosis," EMBO Reports, vol. 7, no. 9, pp. 880-885, 2006.

[5] C. Xu, B. Bailly-Maitre, and J. C. Reed, "Endoplasmic reticulum stress: cell life and death decisions," The Journal of Clinical Investigation, vol. 115, no. 10, pp. 2656-2664, 2005.

[6] H. P. Harding, I. Novoa, A. Bertolotti et al., "Translational regulation in the cellular response to biosynthetic load on the endoplasmic reticulum," Cold Spring Harbor Symposia on Quantitative Biology, vol. 66, pp. 499-508, 2001.

[7] M. Schröder and R. J. Kaufman, "The mammalian unfolded protein response," Annual Review of Biochemistry, vol. 74, pp. 739-789, 2005.

[8] F. Urano, A. Bertolotti, and D. Ron, "IRE1 and efferent signaling from the endoplasmic reticulum," Journal of Cell Science, vol. 113, no. 21, pp. 3697-3702, 2000.

[9] A. Bertolotti, Y. Zhang, L. M. Hendershot, H. P. Harding, and D. Ron, "Dynamic interaction of $\mathrm{BiP}$ and ER stress transducers in the unfolded-protein response," Nature Cell Biology, vol. 2, no. 6, pp. 326-332, 2000.

[10] Y. Kimata, D. Oikawa, Y. Shimizu, Y. Ishiwata-Kimata, and K. Kohno, "A role for $\mathrm{BiP}$ as an adjustator for the endoplasmic reticulum stress-sensing IRE1," Journal of Cell Biology, vol. 167, no. 3, pp. 445-456, 2004.

[11] K. Lee, W. Tirasophon, X. Shen et al., "IRE1-mediated unconventional mRNA splicing and S2P-mediated ATF6 cleavage merge to regulate XBP1 in signaling the unfolded protein response," Genes \& Development, vol. 16, no. 4, pp. 452-466, 2002.

[12] H. Yoshida, T. Matsui, A. Yamamoto, T. Okada, and K. Mori, "XBP1 mRNA is induced by ATF6 and spliced by IRE1 in response to ER stress to produce a highly active transcription factor," Cell, vol. 107, no. 7, pp. 881-891, 2001.

[13] Y. Kozutsumi, M. Segal, K. Normington, M.-J. Gething, and J. Sambrook, "The presence of malfolded proteins in the endoplasmic reticulum signals the induction of glucose-regulated proteins," Nature, vol. 332, no. 6163, pp. 462-464, 1988.

[14] D. Dong, M. Ni, J. Li et al., "Critical role of the stress chaperone GRP78/BiP in tumor proliferation, survival, and tumor angiogenesis in transgene-induced mammary tumor development," Cancer Research, vol. 68, no. 2, pp. 498-505, 2008.

[15] X.-Z. Wang, B. Lawson, J. W. Brewer et al., "Signals from the stressed endoplasmic reticulum induce C/EBP-homologous protein (CHOP/GADD153)," Molecular and Cellular Biology, vol. 16, no. 8, pp. 4273-4280, 1996.

[16] S. J. Marciniak, C. Y. Yun, S. Oyadomari et al., "CHOP induces death by promoting protein synthesis and oxidation in the stressed endoplasmic reticulum," Genes \& Development, vol. 18, no. 24, pp. 3066-3077, 2004.

[17] M. P. Mayer and B. Bukau, "Hsp70 chaperones: cellular functions and molecular mechanism," Cellular and Molecular Life Sciences, vol. 62, no. 6, pp. 670-684, 2005.
[18] E. Schmitt, L. Maingret, P. E. Puig et al., "Heat shock protein 70 neutralization exerts potent antitumor effects in animal models of colon cancer and melanoma," Cancer Research, vol. 66, no. 8, pp. 4191-4197, 2006.

[19] C. Garrido, E. Schmitt, C. Candé, N. Vahsen, A. Parcellier, and G. Kroemer, "HSP27 and HSP70: potentially oncogenic apoptosis inhibitors.", Cell cycle, vol. 2, no. 6, pp. 579-584, 2003.

[20] S. Gupta, A. Deepti, S. Deegan, F. Lisbona, C. Hetz, and A. Samali, "HSP72 protects cells from ER stress-induced apoptosis via enhancement of IRE1 $\alpha$-XBP1 signaling through a physical interaction," PLoS Biology, vol. 8, no. 7, Article ID e1000410, 2010.

[21] J.-S. Seo, Y.-M. Park, J.-I. Kim et al., "T cell lymphoma in transgenic mice expressing the human $H s p 70$ gene," Biochemical and Biophysical Research Communications, vol. 218, no. 2, pp. 582-587, 1996.

[22] A. Samali and T. G. Cotter, "Heat shock proteins increase resistance to apoptosis," Experimental Cell Research, vol. 223, no. 1, pp. 163-170, 1996.

[23] A. Saleh, S. M. Srinivasula, L. Balkir, P. D. Robbins, and E. S. Alnemri, "Negative regulation of the Apaf-1 apoptosome by Hsp70," Nature Cell Biology, vol. 2, no. 8, pp. 476-483, 2000.

[24] C. Bivik, I. Rosdahl, and K. Öllinger, "Hsp70 protects against UVB induced apoptosis by preventing release of cathepsins and cytochrome c in human melanocytes," Carcinogenesis, vol. 28, no. 3, pp. 537-544, 2007.

[25] L. Ravagnan, S. Gurbuxani, S. A. Susin et al., "Heat-shock protein 70 antagonizes apoptosis-inducing factor," Nature Cell Biology, vol. 3, no. 9, pp. 839-843, 2001.

[26] P. J. Muchowski and J. L. Wacker, "Modulation of neurodegeneration by molecular chaperones," Nature Reviews Neuroscience, vol. 6, no. 1, pp. 11-22, 2005.

[27] R. I. Morimoto, "Proteotoxic stress and inducible chaperone networks in neurodegenerative disease and aging," Genes \& Development, vol. 22, no. 11, pp. 1427-1438, 2008.

[28] N. Hosokawa, K. Hirayoshi, H. Kudo et al., "Inhibition of the activation of heat shock factor in vivo and in vitro by flavonoids," Molecular and Cellular Biology, vol. 12, no. 8, pp. 3490-3498, 1992.

[29] D. R. Ferry, A. Smith, J. Malkhandi et al., "Phase I clinical trial of the flavonoid quercetin: pharmacokinetics and evidence for in vivo tyrosine kinase inhibition," Clinical Cancer Research, vol. 2, no. 4, pp. 659-668, 1996.

[30] I. Nicoletti, G. Migliorati, M. C. Pagliacci, F. Grignani, and C. Riccardi, "A rapid and simple method for measuring thymocyte apoptosis by propidium iodide staining and flow cytometry," Journal of Immunological Methods, vol. 139, no. 2, pp. 271-279, 1991.

[31] G. Matusali, G. Arena, A. De Leo, L. Di Renzo, and E. Mattia, "Inhibition of p38 MAP kinase pathway induces apoptosis and prevents Epstein Barr virus reactivation in Raji cells exposed to lytic cycle inducing compounds," Molecular Cancer, vol. 8, article 18, 2009.

[32] G. Marfè, E. Morgante, C. Di Stefano et al., "Sorbitol-induced apoptosis of human leukemia is mediated by caspase activation and cytochrome c release," Archives of Toxicology, vol. 82, no. 6, pp. 371-377, 2008.

[33] M. Raciti, L. V. Lotti, S. Valia, F. M. Pulcinelli, and L. Di Renzo, "JNK2 is activated during ER stress and promotes cell survival," Cell Death \& Disease, vol. 3, article e429, 2012. 
[34] J. I.-J. Leu, J. Pimkina, A. Frank, M. E. Murphy, and D. L. George, "A small molecule inhibitor of inducible heat shock protein 70," Molecular Cell, vol. 36, no. 1, pp. 15-27, 2009.

[35] M. Granato, V. Lacconi, M. Peddis et al., "HSP70 inhibition by 2-phenylethynesulfonamide induces lysosomal cathepsin $\mathrm{D}$ release and immunogenic cell death in primary effusion lymphoma," Cell Death \& Disease, vol. 4, no. 7, article e730, 2013.

[36] B. C. Cross, P. J. Bond, P. G. Sadowski et al., "The molecular basis for selective inhibition of unconventional mRNA splicing by an IRE1-binding small molecule," Proceedings of the National Academy of Sciences of the United States of America, vol. 109, no. 15, pp. E869-E878, 2012.

[37] F. Lisbona, D. Rojas-Rivera, P. Thielen et al., "BAX inhibitor-1 is a negative regulator of the ER stress sensor IRE1 $\alpha$," Molecular Cell, vol. 33, no. 6, pp. 679-691, 2009.

[38] D. Han, A. G. Lerner, L. V. Walle et al., "IRE1 $\alpha$ kinase activation modes control alternate endoribonuclease outputs to determine divergent cell fates," Cell, vol. 138, no. 3, pp. 562-575, 2009.

[39] J. H. Lin, H. Li, D. Yasumura et al., "IRE1 signaling affects cell fate during the unfolded protein response," Science, vol. 318, no. 5852, pp. 944-949, 2007.

[40] E. J. Ryu, H. P. Harding, J. M. Angelastro, O. V. Vitolo, D. Ron, and L. A. Greene, "Endoplasmic reticulum stress and the unfolded protein response in cellular models of Parkinson's disease," Journal of Neuroscience, vol. 22, no. 24, pp. 1069010698, 2002.

[41] A. Szokalska, M. Makowski, D. Nowis et al., "Proteasome inhibition potentiates antitumor effects of photodynamic therapy in mice through induction of endoplasmic reticulum stress and unfolded protein response," Cancer Research, vol. 69, no. 10, pp. 4235-4243, 2009.

[42] C. Hetz, "The unfolded protein response: controlling cell fate decisions under ER stress and beyond," Nature Reviews Molecular Cell Biology, vol. 13, no. 2, pp. 89-102, 2012.

[43] D. T. Rutkowski, S. M. Arnold, C. N. Miller et al., "Adaptation to ER stress is mediated by differential stabilities of pro-survival and pro-apoptotic mRNAs and proteins," PLoS Biology, vol. 4, no. 11, article e374, 2006. 


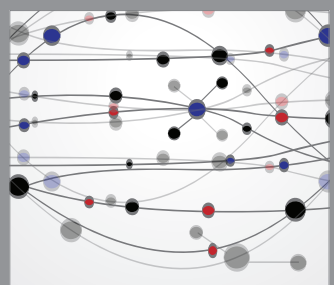

The Scientific World Journal
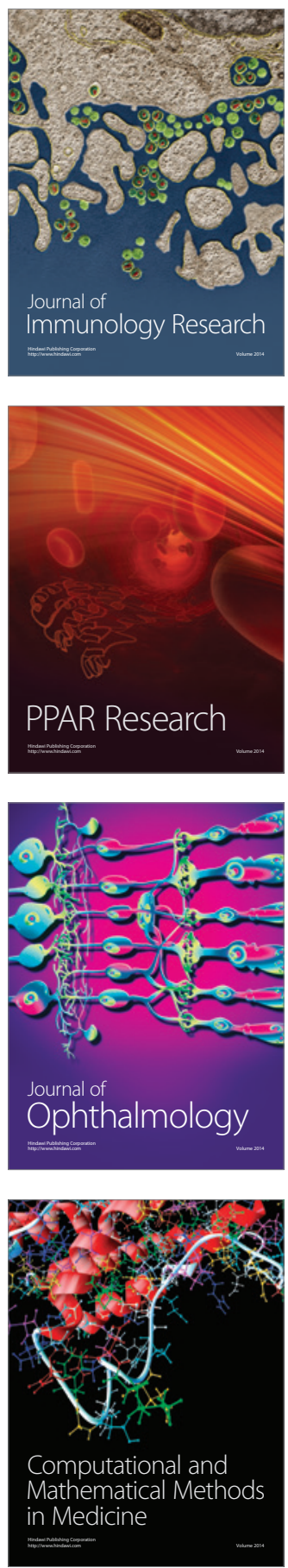

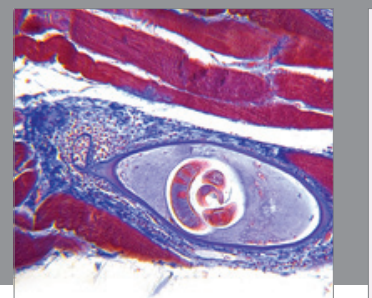

Gastroenterology

Research and Practice
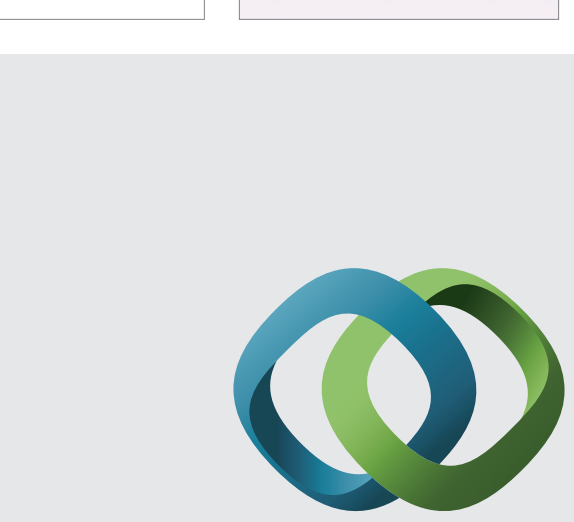

\section{Hindawi}

Submit your manuscripts at

http://www.hindawi.com
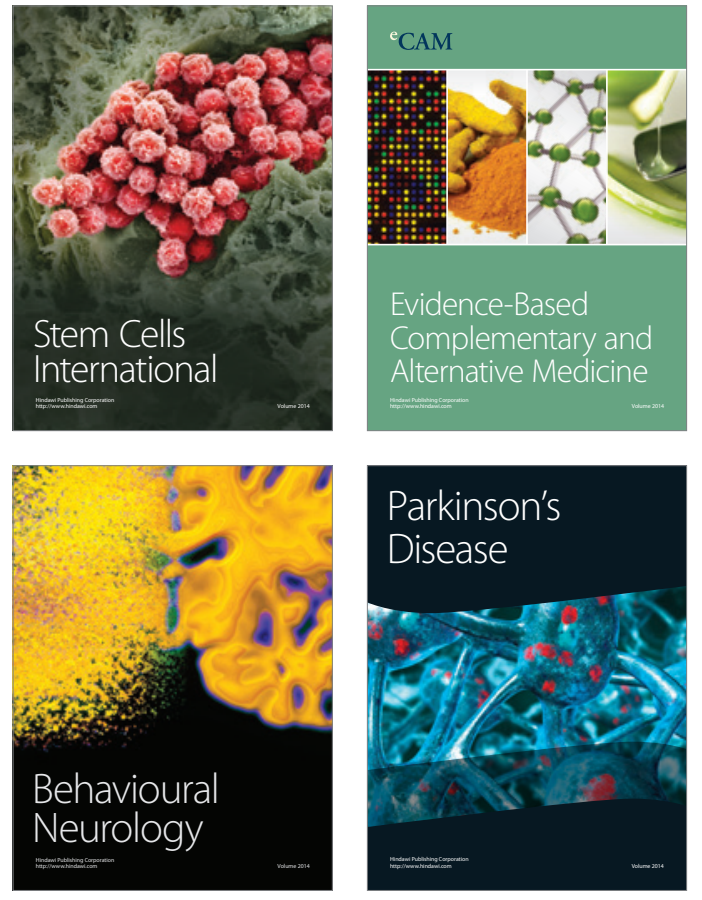
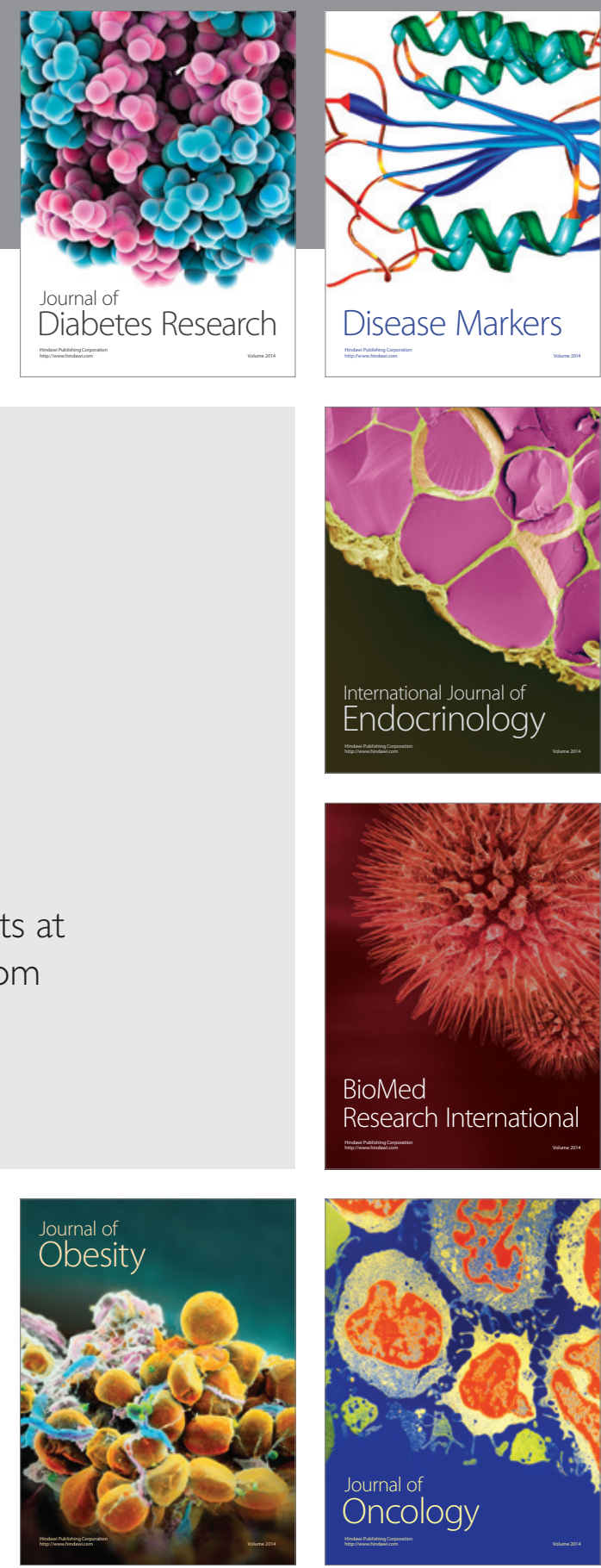

Disease Markers
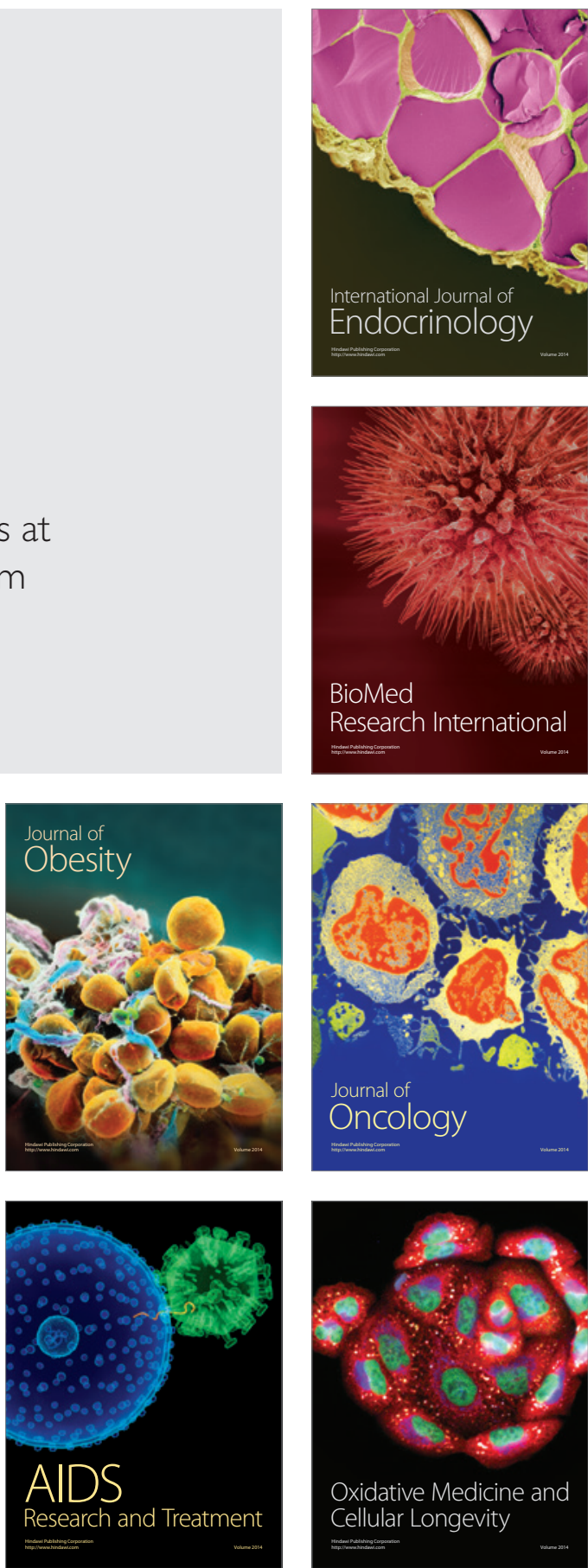